Meta

Journal des traducteurs

Translators' Journal

\title{
The Pragmatics of Professionalism: Translation and Interpretation in Puerto Rico and Quebec
}

\section{James Archibald}

Volume 42, numéro 4, décembre 1997

URI : https://id.erudit.org/iderudit/001900ar

DOI : https://doi.org/10.7202/001900ar

Aller au sommaire du numéro

Éditeur(s)

Les Presses de l'Université de Montréal

ISSN

0026-0452 (imprimé)

1492-1421 (numérique)

Découvrir la revue

Citer cet article

Archibald, J. (1997). The Pragmatics of Professionalism: Translation and Interpretation in Puerto Rico and Quebec. Meta, 42(4), 649-660.

https://doi.org/10.7202/001900ar

\section{Résumé de l'article}

L'auteur traite des répercussions possibles de la loi de 1993 instituant le bilinguisme (espagnol, anglais) à Porto Rico. Il décrit l'impact que les lois linguistiques peuvent avoir sur l'activité traductionnelle et, mettant en parallèle la situation portoricaine et celle du Québec, il explique comment ces lois peuvent affecter le développement national et économique d'un pays. 


\title{
THE PRAGMATICS OF PROFESSIONALISM: TRANSLATION AND INTERPRETATION IN PUERTO RICO AND QUEBEC
}

JAMES ARCHIBALD

McGill University, Montreal, Canada

Résumé

L'auteur traite des répercussions possibles de la loi de 1993 instituant le bilinguisme (espagnol, anglais) à Porto Rico. Il décrit l'impact que les lois linguistiques peuvent avoir sur l'activité traductionnelle et, mettant en parallèle la situation portoricaine et celle du Québec, il explique comment ces lois peuvent affecter le développement national et économique d'un pays.

\begin{abstract}
This article discusses the impact of official language policy on translation following the adoption of a 1993 law establishing Spanish/English bilingualism in Porto Rico. Using Quebec's official language legislation as an example, the author studies the possible longlasting effects of language policy on the national and economic developemnt of Puerto Rico.
\end{abstract}

On 28 January 1993, the Legislative Assembly of Puerto Rico adopted a controversial piece of legislation re-establishing official bilingualism in the Commonwealth. ${ }^{1}$ The Law stated that "el español y el inglés serán los idiomas oficiales del Gobierno de Puerto Rico, y que ambos se podrán utilizar indistintamente."

This Law upset the historic reversal of the status of the English language under the Law of 5 April $1991,{ }^{2}$ which stated that:

el español será el idioma oficial de Puerto Rico a usarse en todos los departamentos, municipios $u$ otras subdivisiones políticas, agencias y dependencias gubernamentales de la Ramas Ejecutiva, Legislativa y Judicial del Estado Libre Asociado de Puerto Rico y para derogar la Ley de 21 de febrero de 1902, "Ley con respecto al idioma que ha de emplearse en los Departamentos, Tribunales y Oficinas del Gobierno Insular".

The 1902 legislative text stated that "se emplearán indistintamente los idiomas inglés y español" 3 in all the courts and public offices.

Previously, at the time of the American conquest of both Puerto Rico and Cuba, the Adjutant General issued Order No. 192 to deal with this situation. This Order was published in the Gaceta de Puerto Rico on 27 January 1899.

Por disposición de Secretario de la Guerra, todos los documentos ejecutados en inglés y presentados para su inscripción en Cuba y Puerto Rico, cuando vengan acompañados de la correspondiente traducción al castellano, tendrán, inscritos que sean, la misma fuerza y validez que si fuesen extendidos en castellano. ${ }^{4}$

Against this brief historical backdrop, it is clear that the current administration felt that returning to a situation very reminiscent of 1902 would be politically expedient. By recognizing the co-equal status of both English and Spanish in 1993 the Commonwealth's

Meta, XLII, 4, 1997 
government saw a significant benefit for Puerto Rico's development since it would be in a better position to take advantage through the United States of its privileged relationship with the expanding North American trading bloc, to become more competitive in that market and to achieve greater socio-economic progress for Puerto Ricans.

The Governor of Puerto Rico, a 48-year-old Yale graduate called Pedro Roselló, saw the issue as a pragmatic one in that the new law would allow his government to "propiciar el desarrollo económico de Puerto Rico por la ventaja competiva que representa utilizar los dos idiomas." 5 He puts his political position into perspective in this way.

El inglés y el español coexisten desde 1902 y no ha habido nunca une amenaza al vernáculo como lengua de comunicación social en Puerto Rico. El español ha predominado y lo seguirá haciendo en la interacción diaria de los puertorriqueños. Lo que alteró el orden establecido fue la Ley del 5 de abril de 1991 que eliminaba el inglés como idioma oficial. Esa ley limitaba nuestro desarrollo como pueblo, especialmente cuando observemos que en el hemisferio americano se están levantando las barreras tarifarias y existen dos idiomas y dos culturas predominantes. El hecho de que Puerto Rico se pueda beneficiar de esas dos culturas, y no de una sola, nos coloca en una posición privilegiada, competitiva y de progreso. ${ }^{6}$

How then does the official language issue impact on translation? The 1991 law provided for translations and interpretations so that official proceedings could be readily understood by speakers of both Spanish and English. The 1993 law recognizes English as a second language, which does not intimate that native Spanish speakers surrender any of their historically acquired rights. Therefore, English is presented as one of the "vehiculos prácticos para que el Gobierno de Puerto Rico pueda continuar comunicándose en forma efectiva con su pueblo y el mundo exterior."7 Although the term segundo idioma is used in the preamble to Law 1 of 28 January 1993, the spirit of the legislation is to see it more as an "auxiliary language" given a special status to help in the political and economic development of Puerto Rico. ${ }^{8}$ This meets with a certain current of political thought in Puerto Rico whereby English "is generally presented as the key to prosperity." Hence, in a pragmatically bilingual Puerto Rico the cultural tradition of a Spanish-speaking nation is maintained as a marker of identity ${ }^{10}$ while the economic imperative of national development is enhanced through the widespread official use of the "auxiliary language."

This position reinforces the current official view to the effect that the Law of 28 January 1993 would enable the creation of wealth in a harmonious national and international market.

In economic terms, the Government presents the island as politically stable and economically strong as compared to its Caribbean neighbors. Although "the average per capita personal income... in fiscal 1992 was the highest in Latin America," it is only about $36.7 \%$ of the mainland average. The infrastructure in place is also one which will support economic growth. This includes the banking system, telecommunications, transportation, utilities, the postal system, etc. The labor force of about 1.2 million is more highly skilled than ever before with non-agricultural industries providing over $97 \%$ of employment. Approximately $49 \%$ of the labor force consists of white collar workers (professional, managerial, clerical and sales); this group includes the small number of professional translators and interpreters practicing in Puerto Rico. Also, the labor force is relatively literate by Caribbean standards. Compulsory universal education is enforced. Currently over 160,000 young Puerto Ricans in the $20-24$ age group, that is $54 \%$ of this cohort, are enroled in institutions of higher learning and preparing for the professions or technical occupations. ${ }^{11}$ This includes translation and interpretation which is taught at the University of Puerto Rico. Translation is one of the newer professions. "En 1970, la Escuela Profesional de Traductores de la Universidad de Puerto Rico habilito un programa experimental que 
posteriormente se denominara Programa Graduado en Traducción y que otorga el grado de Magister:"12 This followed a Latin American trend which started in 1945.

Notwithstanding this trend, there are today no more than seventy-four (74) translators who are members of the Professional Association of Translators and Interpreters of Puerto Rico (PATIPR). ${ }^{13}$ Hence, out of a white collar labor force of 588,000, PATIPR members account for a mere $0.01 \%$ of Puerto Rico's knowledge workers; yet, it is this small army of word crafters which is being given so great a role in economic development by the current administration.

The Puerto Rican government expects the Commonwealth's economy to continue to grow in 1994, projecting a real growth rate of three percent (3\%). This will play itself out against a backdrop of political stability, Puerto Ricans having opted for continued associate status with the United States and having elected a pro-American governor. The independence option has consistently been supported by only $5 \%$ or less of voters for well over ten years now.

Further, as stated above, the North American Free Trade Agreement (NAFTA) has fuelled even higher expectations for economic growth. "Puerto Rico's favorable investment environment, highly skilled labor force, infra-structure development and tax structure would tend to create expanded trade opportunities for the Island in such areas as pharmaceutical and high technology manufacturing."14

Both translators and interpreters will have their role to play as members of an emerging social class responsible for economic development. Despite the positive economic indicators noted above, one hard reality is that out of 2,026,092 Puerto Ricans in the 18-64 year-old cohort, only 581,134 speak English easily (28.7\%). Out of this same cohort 1,416,063 Puerto Ricans are either unable to speak English or speak it with difficulty. This represents $69.9 \%$ of the cohort. ${ }^{15}$ It seems clear then that the socio-linguistic data support the government's expectation that translation and interpretation will play a role in further economic development.

The issue is not, however, solely one of economic development. The linguistic imbalance in the population and the traditional resistance of the population to learn English in addition to the role of English in the court system underscore the importance of ensuring linguistic access to governmental processes. In addition to language legislation having been passed since the beginning of colonial status in Puerto Rico, "Puerto Rico's Supreme Court has rendered decisions on language four times since 1898." In her article on the language debate in Puerto Rico, Diana L. Vélez points to the importance of court rulings in the development of translation and interpretation in Puerto Rico. ${ }^{16}$ More particularly, she points to the historical assumption that as American citizens Puerto Ricans were expected to learn English in order to enjoy their legal rights, this despite the fact that the United States did not have an official languages act in 1898 no more than it does today. Access to rights in the US court system has always been more or less a matter of pragmatics with untrained and often unqualified persons acting as translators and interpreters who have served non-English speakers who would otherwise have been unable to exercise their rights as citizens. Issues of concern have been interpretation during proceedings, the translation of evidence and official documents, the understanding of testimony and charges by all parties.

A most useful overview of the problems of language use in the Puerto Rican court system is found in the statement by the Hon. Francisco de Jesus Schuck, former Secretary of Justice of the Commonwealth of Puerto Rico before the Subcommittee on Improvements in Judicial Machinery (1974). He pleaded for the use of Spanish in the US District Court for the District of Puerto Rico. This position had the support of all judges on the Federal Court in Puerto Rico as well as the Puerto Rican Bar Association. All parties seemed to 
be of a common accord to eliminate this offensive symbol of colonial domination and this obstacle to the full exercise of legal rights and protection under due process. ${ }^{17}$

Martin H. Gerry, the Officer for Civil Rights in the Department of Health, Education and Welfare, also pleaded for language rights in the court system stating that "defendants in both criminal and civil procedures be entitled as a matter of right to oral translation of all testimony, argument, instructions to the jury, and other communication which takes place in the courtroom." Not to do so would be a "mockery of the courts." Gerry further pointed out that "the basic guarantees of the Bill of Rights and the common law tradition [cannot] be maintained for a defendant who has no way of understanding what is transpiring around him." Hence to deny translation is "discriminatory," because this act is one of "inherent inequality." 18 In this way civil rights proponents argue for more extensively bilingual courts in all jurisdictions in both civil and criminal matters "in order to implement both due process and equal protection guarantees of the $14^{\text {th }}$ amendment."19 Translation is therefore seen as a basic right rather than a privilege to be granted at the whim of the court.

If English were to be used to the exclusion of Spanish, $69.9 \%$ of Puerto Ricans in the 18-64 year-old cohort would be denied their basic rights and $79.3 \%$ of Puerto Ricans over 65 years of age ${ }^{20}$ would not benefit from full protection under the law. Clearly this social reality demonstrates the need to address these issues in the Puerto Rican context, and it further demonstrates the socio-economic role to be played by translators and interpreters in Puerto Rico.

This situation has been the source of regular friction.

In Federal Court in Puerto Rico, all proceedings are held in English and there is no official recognition of Spanish. According to Alfonso García Martínez, in governmental spheres only the Puerto Ricans have to be bilingual, surely a double standard: "En la esfera federal nunca ha habido bilingüismo oficial. ${ }^{21}$

As stated above, translations were made in governmental institutions from the time of the American conquest as pragmatically required. The principle is set-out in Order $\mathrm{N}^{\circ} 192$ cited above and in the official language legislation of 1902: "cuando sea necesario, se harán traducciones y interpretaciones." 22

The law of 5 April 1991, although it appears to create a monolingual polity, is very clear on the issue of translation and interpretation.

Cuando ello fuere necesario se harán traducciones escritas e interpretaciones orales, de y al idioma inglés, según sea el caso, de modo que las partes interesadas puedan comprender todo procedimiento o comunicación en el idioma que más les convenga, conforme a la reglamentación previamente aludida que se adopte. ${ }^{23}$

This text could even be taken as direct response to the issues raised by Gerry at the 1974 Senate hearings on improvements in judicial machinery. However, in the case of the 1991 Law the government's policy as translated into law reaches out to all three branches of the Commonwealth's government: legislative, executive and judicial.

Notwithstanding the monolingual nature of the polity, Article 3 of the 1991 Law goes even further in its largesse:

Por excepción, las tres Ramas del gobierno podrán utilizar en sus transacciones y documentos, y de igual manera podrán mantener expedientes o parte de ellos, en otro idioma [English] cuando ello fuere conveniente, necesario o indispensable, y de conformidad con las normas que se establezcan por regla o reglamento. En el caso de dependencias, agencias y corporaciones públicas de la Rama Ejecutiva que interesen hacer uso de la excepción dispuesta en este Artículo, deberán solicitar autorización previa del Gobernador... ${ }^{4}$ 
Despite the obvious effort of the legislator to deal with the civil rights of Puerto Ricans with specific regard to language, translation and interpretation, the government and its agents are called upon to exercise considerable discretionary power. Nonetheless, the Law seeks to allay any fears by stating quite clearly that "Las disposiciones de esta ley no limitan en modo alguno los derechos constitucionales de ninguna persona."25

The law of 28 January 1993 "Se deroga en su totalidad la Ley Núm. 4 de 5 de abril de 1991,"26 Notwithstanding Article 7, the 1993 Law repeats almost verbatim Article 2 of the 1991 text cited above. The new legal text reads as follows:

Cuando ello fuere necesario se harán traducciones e interpretaciones orales o escritas, de un idioma al otro, de modo que las partes interesadas puedan comprender cualquier procedimiento o comunicación en dichos idiomas. ${ }^{27}$

This article addresses the same question of rights as the 1991 law, and translators and interpreters are still called upon to play the same socio-economic role as before.

In the same spirit, Article 3 of the 1993 Law parallels Article 3 of the 1991 text.

Los departamentos, municipios, y otras subdivisiones politicas, agencias, corporaciones públicas, oficinas y dependencias gubernamentales de las Ramas Ejecutiva, Legislativa y Judicial del Estado Libro Asociado de Puerto Rico emplearán, cuando fuese necesario, intérpretes y traductores competentes para llevar a cabo de la disposiciones de esta ley. ${ }^{28}$

Both the 1991 and 1993 texts give all branches of the government considerable discretionary power to determine when translation and/or interpretation may be needed; both texts state unequivocally that basic constitutional rights will not be violated. Eventually, jurisprudence will have to serve as a guide in understanding the legal text and that of regulations which may later be adopted under this type of framework legislation.

The new element added in 1993 is one of a qualitative nature since the law states that under Article 3 translators and interpreters must be competent. If the government must employ competent translators and interpreters, how is it supposed to distinguish between those who may have attained the required level of competency and those who may not have done so? What measure is to be used? What is the marker of professional competency?

Despite Governor Roselló's contention that translation and interpretation will have an economic role in Puerto Rico's development, his government's legislation only affects the activities of the Commonwealth's government. To date, there is "no legislation regarding the use of Spanish in work places or forcing commercial advertising to be in one language or both." 29 Hence, the Puerto Rican government has not addressed language rights in the market-place outside government institutions and the state school system.

Despite this lack of legislation, Spanish is the language of the workplace and many American businessmen in Puerto Rico find they must learn it if they hope to bypass the foreman, who, until then, must act as his translator. ${ }^{30}$

And who is to ensure that commercial translations so necessary for Puerto Rico's economic development are done by competent translators? How is the user public protected from poor quality translation and professional charlatanism if the government takes no action in this regard? Muñiz-Arguelles further notes that many professionals also serve as translators out of necessity. Examples cited are law, medicine and engineering where professionals specialized in areas other than translation are called upon almost daily to produce translated texts or to interpret in professional or business contexts. Given the economic impact of these acts of translation and interpretation, what guarantees of quality or competency exist?

An anecdote illustrates this reality. Irma Balzac, who served is head of the Bureau of Translations in the Supreme Court of Puerto Rico from 1949 to 1968 started out working 
for Justice Wolf in 1934. Her real role was to serve as an English Proof Reader and Stenographer. However, since Justice Wolf, an American who spoke no Spanish, needed to understand proceedings and communication in and around the court, to paraphrase the laws of 1991 and 1993, Mrs. Balzac was initiated into the work of translation. To top it off, the head of the Court's translation department at that time could only read Spanish and had no oral proficiency. During this period (1930-1940) several volumes of the Puerto Rico Reports were "translated and published by the Law Clerks of the Justices of the Supreme Court" not by professionally competent or certified translators. It is for this reason that the Reports were prefaced by "excusas por cualquier error que pudiera resultar de su falta de experiencia en ese tipo de trabajo." Mrs. Balzac slowly grouped together a number of people who over time and as a result of experience developed the necessary competencies. This group came to be known as La Sororidad de Irma, ${ }^{31}$ thus denoting the collegiality of the relationship among the Court's translators as well as the gender of the workers. Translation was seen as women's work, of lower professional status than legal, engineering or medical acts which were mostly performed by males.

Even today translations of government regulations "are usually made in-house by the personnel of the agency in question (non-trained translators) or by professional translators contracted to do the work." 32 Out of the seventy-four (74) translators in PATIPR thirty-four claim to be specialists in legal translation, that is $46 \%$ of the body, and the Association distributes over two thousand copies of its Directory to both the public and private sectors where there is a need for competent legal translation and other types of translation. The members' other speciality areas are technical-industrial, commercialadvertising, banking-insurance, literary and medical-scientific.

Twenty-one (21) members only specialize in medical-scientific translation, that is $28.4 \%$ of total membership despite the fact that the major economic growth industry in Puerto Rico should be the pharmaceutical industry as noted above. Will this group of professionals be able to meet the need for competent scientific translations or, as in the case of government, will companies such as Abbott Laboratories Inc., Baxter International Corporation, Johnson and Johnson Corporation, Brystol-Myers-Squibb Co., Warner Lambert Co., American Cyanamid Co., American Home Products Inc., Dupont E.I. DuPont Nemours Inc. and Eli Lilly and Co. resort to non-trained in-house translators? In order to appreciate the magnitude of the issue all nine pharmaceutical manufacturing operations cited above employ over 1,000 workers each; two employ between 1,500 and 2,499 and three employ in excess of 2,500 workers each. ${ }^{33}$ Are 21 freelance professional translators enough to meet the needs of what is a large business sector and one which the government has targeted for significant future growth including increased exports to American markets using languages other than Spanish? Although we have not mentioned the French-speaking element of the North American Free Trade area, it does exist and only two professional, medical-scientific translators are able to translate from English or Spanish into French, i.e.: $2.7 \%$ of the membership.

A cursory examination of the situation clearly suggests a lack of qualified professionals to carry out the translation work needed to build a stronger Puerto Rican economy. The current president of PATIPR holds the government responsible for playing politics with language legislation while neglecting the socio-economic and legal issues of promoting a strong translators' profession. "The government of Puerto Rico has not done anything to license or qualify... professionals" 34 in translation and interpretation.

One can only hear the frustration in Olga Lasa's voice. She contends that the 1993 law "will add nothing new to our economic development or progress." Far from recognizing the pragmatics of proposed governmental action in this area, the leader of Puerto Rico's translators takes quite the opposite stand stating that this legislative initiative was politically inspired and "totally divorced from our cultural, economic, and linguistic reality." 35 
The official position of PATIPR with reference to language legislation was set out in El Trujamán in 1992.

The language professionals in Puerto Rico feel strongly that the government has a role to play in protecting the public interest by ensuring that the public be given a means to recognize quality translation and that both the public and private sectors be provided with some mechanism to distinguish the qualified translator from those who are not. Concretely, PATIPR proposes that government create an Examining Board (Junta Examinadora) to test and license translators and a College of Translators (Colegio de Traductores), which would have official regulatory responsibility in managing the profession.

If the government does not opt for this orientation, it should maintain an official roll of certified translators. The government's Oficina Central de Administración de Personal (OCAP) would then be charged with examining candidates to be added to the roll.

A possible third alternative would be to use the State Department's Register of Translators and Interpreters. Clearly, this is not the preferred solution. ${ }^{36}$

PATIPR would obviously be poised to transform itself into the Colegio de Traductores and possibly administer the Junta Examinadora. PATIPR has already established itself as a credible professional association providing professional development for its membership and setting standards for the membership's ethical behavior. ${ }^{37}$

In the meantime, no such practical approach to professional organization currently exists in Puerto Rico. In the view of language professionals already in place government has not gone far enough in protecting the public interest and in assuring the highest possible professional standards. Translators and interpreters have taken it upon themselves to regulate their own activities.

Although, as stated above, the PATIPR President sees the government's recent attempts at linguistic legislation as political opportunism, PATIPR does, however, recognize that this type of language legislation, because of its references to translation activity, is "una puerta abierta para darle a nuestra profesión credibilidad y altura." 38

At this juncture it is seen as an opportunity to be exploited which may lead to greater professionalism and a higher level of protection offered to the citizenry and other users of translation services. Should PATIPR's position gain credence in government circles, it could be transformed into an official regulatory body with licensing powers, and PATIPR could become a more effective organization to promote at the same time as it protects the public interest the economic interests of its own membership. This would represent a significant shift from the Sororidad de Irma, whose numbers were exploited by government. A new, para-governmental body would have as its principle role to protect the public interest, to contribute to economic development and to guarantee the professionalism of translators and interpreters in Puerto Rico.

Should government adopt in whole or in part PATIPR's proposals, the Puerto Rican government would also have to consider the eventual impact on its educational policy. The new policy would have to value individual Puerto Ricans' "ability to communicate in more than one language" 39 and to establish this as an educational priority from the lower levels of education where both English and Spanish as well as other languages may be effectively taught to the post-secondary levels of education where professional programs in translation and interpretation would have to be reinforced and enhanced. The government should then adopt policies of higher education which would ensure that prospective professional translators and interpreters have the opportunity to earn the diplomas required to gain access to professional status. The cost will be significant, but the government has already said in its current policy that the economic benefit will be the development of a stronger Puerto Rican economy. 
Although the door to the professionalization of translation and interpretation in Puerto Rico has been opened, the movement has progressed at a more accelerated pace in the context of Quebec's linguistic policy.

Similarly to Puerto Rico, Quebec has emerged for a colonial past where two languages, English and French, have shared the same stage since the early attempts of France and Britain to establish their dominion over North America. Linguistic legislation, as we have seen above, is not extensive in Puerto Rico, and although the current administration has opened the door to broader government intervention in linguistic matters, Quebec's body of linguistic and related legislation is much more extensive.

Of fundamental importance to Quebec society is the existence of the British North America Act of 1867, Canada's constitutional law, which establishes the principle of institutional bilingualism in the legislature and the courts. Both English and French remain the official federal languages in these two areas. Faced with the threat of linguistic assimilation by the rest of English-speaking Canada and cultural invasion from the United States, Quebec has adopted a series of measures establishing in law the place of the French language in Quebec.

Current official language legislation in Quebec, the Charter of the French Language, focuses not only on the official language of government but also on the rights of workers and consumers to use the official language in their work and private lives. Hence, the spirit of the Charter is more all-encompassing than that of the last two official language laws adopted by the Legislative Assembly of Puerto Rico. The focus is more clearly on fundamental linguistic rights including language as it is used at work, in trade and commerce, in schools and in the professions. ${ }^{40}$ The basic principle is that citizens have the right to be served and to have their needs met in French. The English language is not given co-equal status in the Charter; yet, in specific instances another language such as English may be used.

The Charter also interfaces with other laws to provide a comprehensive application of linguistic policy. This includes professional legislation.

The Charter does not, however, address the issue of translation. With regard to the courts and the legislature, the principle to be held up is that of institutional bilingualism. This principle is also found in Federal legislation, where under the Criminal Code an accused may elect to be tried in either of Canada's official languages and may even elect to be judged by a mixed jury in linguistic terms. ${ }^{41}$ Therefore, the rights of the individual citizen are paramount. In cases where a given institution may not be bilingual, the courts may appoint translators or interpreters whom they deem to be competent. Hence, the Canadian citizen in the Quebec or Federal court system is not to be isolated linguistically, and the individual is not denied due process for linguistic reasons. This has a very practical impact on the everyday workings of the federal and provincial court systems in Quebec.

Another piece of Quebec legislation also focuses on protecting individual citizens as consumers and users of professional services. The overriding purpose of Quebec's Professional Code is to guarantee that any recognized professional practicing in Quebec is licensed by a professional body which "a pour principale fonction d" assumer la protection du public." 42

In 1992 the Société des traducteurs du Québec (STQ), the premier professional association for translators in Quebec, became the Corporation professionnelle des traducteurs et interprètes agréés du Québec (CPTIAQ), thereby assuming the responsibilities of a licensing authority and a professional college. ${ }^{43}$

Whenever the Quebec government establishes a professional body of this nature, it must take into account a number of factors including the level of training required to practice as a professional, the degree of autonomy, the client relationships and two other major factors: 
1. La gravité du préjudice ou des dommages qui pourraient être subis par les gens recourant aux services de ces personnes par suite du fait que leur compétence ou leur intégrité ne seraient pas contrôlées par la corporation.

2. Le caractère confidentiel des renseignements que ces personnes sont appelées à connaître dans l'exercice de leur profession. ${ }^{44}$

Although the STQ had requested exclusive rights of practice under the Code, the Quebec government judged it sufficient to recognize translators and interpreters as a reserved title corporation without exclusive rights of practice. Hence, a member of the public or a government official has the option of employing a recognized professional or an individual who operates outside the strictures of the Professional Code. If the user public engages the services of a professional translator, that person benefits from the full measure of protection provided under the Code. If not, the law of the market-place applies.

One of the legal measures of protection consists in the fact that any professional holding the right to practice in Quebec must have a knowledge of the official language sufficient for the practice of his/her profession. Moreover, under the Code the practicing professional is legally bound by the Corporation's Code of Ethics, which has force of law. CPTIAQ's Code was published in the Official Gazette in September 1993. This Code outlines the duties of the professional translator with respect to the public, clients and the profession. ${ }^{45}$

The Quebec Government, not satisfied with the current level of protection, intends to go even further by reforming the Professional Code in order to:

...discipliner davantage les corporations professionnelles, qui auront ainsi plus de comptes à rendre à l'Office des professions que par le passé. ${ }^{46}$

Practically speaking, Quebec has walked through the symbolic door which has been opened by the current Puerto Rican administration and has gained a great deal of experience in meeting the legislative objectives which PATIPR has set for itself.

The road is a similar one. A more in-depth study of the professionalization of translation in Quebec would without doubt be of service in helping practicing translators map out a pragmatic strategy to establish a College of Translators with the legal authority to license and discipline practicing translators and to assure a greater measure of protection for those using translation services in the polity.

It remains to be seen whether the measures taken by government in Puerto Rico and Quebec will truly have an economic impact. There is little data available on the economic value of translation in Puerto Rico given that this area of activity has yet to achieve recognized professional status. In the Quebec context, it appears "difficile, voire impossible, d'analyser [...] les effets économiques de la traduction." 47 Further, it seems astounding that, given the expanded role played by translation in Canadian society, "no study has been conducted to evaluate the true economic spin offs of translation in Canada." 48

There is, however, a generally accepted recognition of translation's role in the cultural, social, legal and commercial life of a bilingual or multilingual polity. In her analysis of the Puerto Rican debate on linguistic policy, Diana Vélez concludes by stating that the "ambivalence of Puerto Ricans with reference to English is a result of their perception of themselves as a culture under siege." 49 This is not dissimilar to the attitude of Quebecers as described by Sherry Simon in her study of translation and linguistic policy in Quebec which could be called a first attempt to write a sociologie de la traduction. ${ }^{50}$

Practically, it is recognized that without the proper level of training the professional cannot "achieve the legitimacy accorded to a professional occupation" and that "certification by examination must become mandatory." 51 Although this view expressed by Virginia Benmaman focuses specifically on legal interpreting, the position could be extended to 
other specialty areas of the translation and interpretation professions as Quebec has done through the inclusion of CPTIAQ under the Professional Code.

Notwithstanding the paucity of economic impact studies, most socio-linguists and political scientists recognize that language policies in the national context will have an economic impact. ${ }^{52}$ Carrying on in the tradition of well founded views presented by major thinkers in the area such as Elie Kedourie and Joshua Fishman, Louis-Jean Calvet sums it up succinctly, underscoring the link between language planning through legislative, regulatory, judicial and administrative processes and economic development.

La planification linguistique relèverait du domaine du développement et plus particulièrement du développement national, se trouvant ainsi en relation, d'une part, avec l'État considéré comme instance de décision et, d'autre part, avec ces interventions de l'État que sont les politiques économique, sociale, etc. ${ }^{53}$

The effect according to Calvet is to put without question "la planification linguistique du côté des interventions étatiques de type économique." 54

In conclusion, both PATIPR and Governor Roselló's administration are correct. Puerto Rico's linguistic policies are surely politically inspired and will most likely continue to be so. There will certainly be a long-term economic impact; this will be developmental in nature, and translation, if properly developed as an area of economic activity, will have a long-lasting effect on the national and economic development of Puerto Rico. The door has been opened on such a development policy in Puerto Rico, and the experience of Quebec, which has now officially recognized the role translators and interpreters have to play in its national and economic development, could well serve Puerto Ricans as a living example of translation's economic value in a pragmatically bilingual polity.

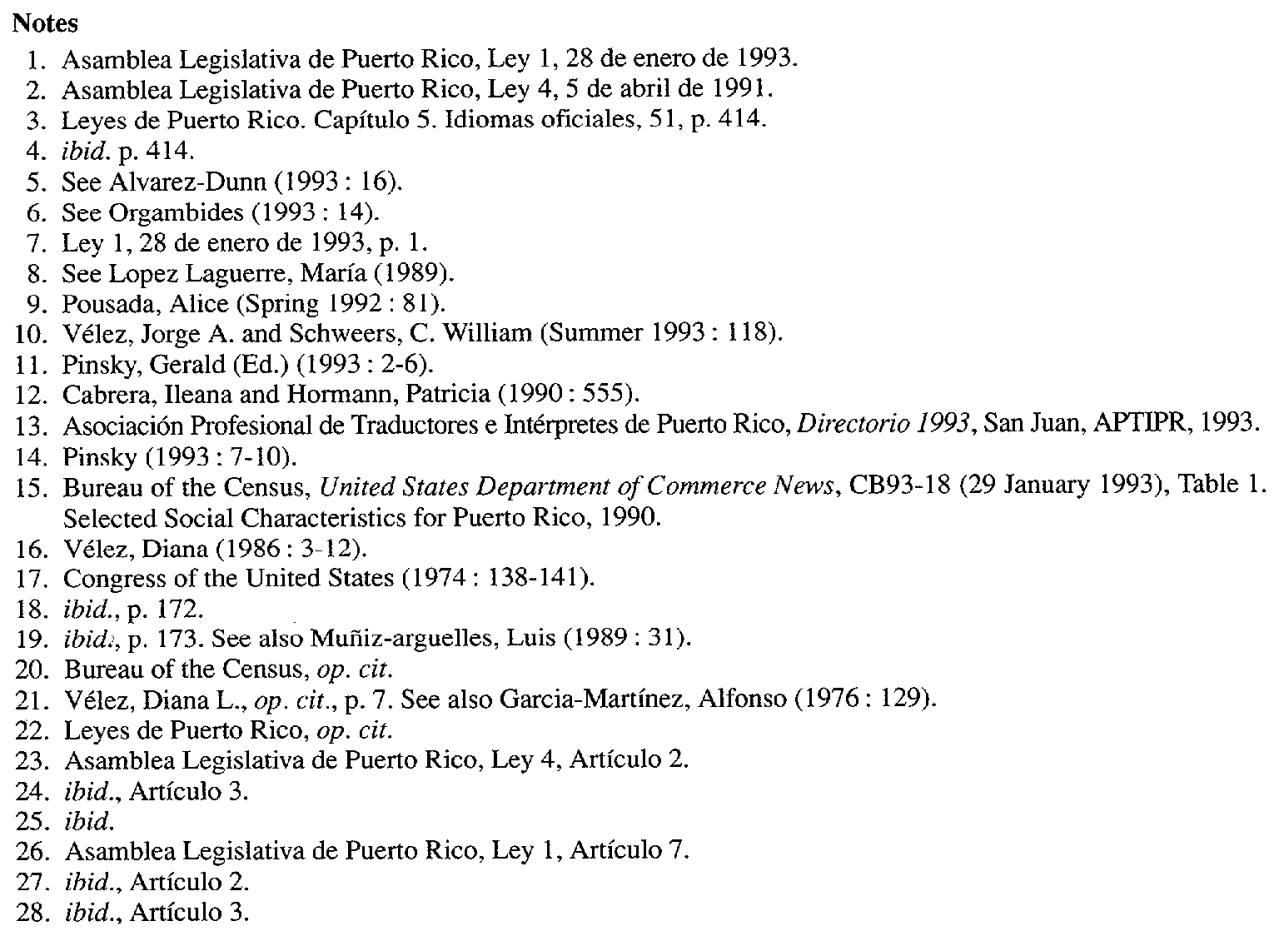


29. Muñiz-Arguelles, Luis, op. cit., p. 32.

30. ibid.

31. Lasa, Olga, Paniagua, Blanca y Ramos, Lilliana (1993 : 3-5).

32. Lasa Delgado, Olga, Private communication, 28 February 1994.

33. Pinsky, Gerald (Ed.), op. cit., p. 15.

34. Lasa Delgado, Olga, op. cit.

35. ibid.

36. Lasa Delgado, Olga (1992: 14-15).

37. Asociación Profesional de Traductores e Intérpretes de Puerto Rico, Codigo de Ética, 1993.

38. Lasa Delgado, Olga, op. cit., p. 15.

39. Bailey, Max A. (1993: 37).

40. Gouvernement du Québec (1978).

41. Greenspan, E. L. (Ed.) (1993). See section 530-534, cc $766-$ cc 772.

42. Gouvernement du Québec (1991).

43. Corporation professionnelle des traducteurs et interprètes agréés du Québec (1993: 6). See also Delisle, Jean (1990)

44. Gouvernement du Québec (1991) Article 25.4 - 25.5 .

45. Code de déontologie de la Corporation professionnelle des traducteurs et interprètes agréés du Québec, Gazette Officielle du Québec, 29 septembre 1993, $125^{\mathrm{e}}$ année, $\mathrm{n}^{\circ} 41,6896-6899$.

46. Boyer, Hélène (1993: E-1)

47. Simon, Sherry (1989:16)

48. Laframboise, Gilles (1992: 7).

49. Vélez, Diana, op. cit., p. 10.

50. Simon, op. cit, p. 12.

51. Benmaman, Virginia (1992: 451).

52. See Fishman (1972) and Kedourie (1993).

53. Calvet, Louis-Jean (1986: 18).

54. ibid.

\section{REFERENCES}

ALVAREZ-DUNN, Claudio (1993): "La isla de la lengua bifida", Cambio, 8, Feb., p. 16.

Asamblea Legislativa de Puerto Rico (1993): Ley 1, 28 de enero de 1993.

Asamblea Legislativa de Puerto Rico (1991): Ley 4, 5 de abril de 1991.

Asociación Profesional de Traductores e Intérpretes de Puerto Rico (1993): Codigo de Ética, San Juan, APTIPR.

Asociación Profesional de Traductores e Intérpretes de Puerto Rico (1993): Directorio 1993, San Juan, APTIPR.

BAILEY, Max A. (1993): "Bilingual Education: Legal Perspectives and Policy Considerations", Illinois Schools Journal, 72 (2), p. 37.

BENMAMAN, Virginia (1992): "Legal Interpreting: An Emerging Profession", The Modern Language Journal, 76 (IV), pp. $445-454$.

BOYER, Hélène (1993): "La réforme du Code des professions", Le Devoir, 9-10 octobre, pp. E1 \& E10.

CABRERA, Ilana and Patricia HORMANN (1990): "Hacia un programa curricular común de traducción para América Latina", Meta, 35 (3), pp. 552-560.

CALVET, Louis-Jean (1986): "Typologie des politiques linguistiques", États de langue, Max-Peter Guenais (dir), Paris, Fayard.

Corporation professionnelle des traducteurs et interprètes du Québec (1993): "Code de déontologie", Gazette Officielle du Québec, 41, 29 septembre, pp. 6896-6899.

Corporation professionnelle des traducteurs et interprètes du Québec (1993): Rapport Annuel 1992-93, Montréal, CPTIAQ.

Congress of the United States (1974): Hearings before the Subcommittee on Improvements in Judicial Machinery of the Committee on the Judiciary, United States Senate, Ninety Third Congress, Second Session on S1724, A Bill to Amend Title 28, United States Code, to Provide More Effectively for Bilingual Proceedings in Certain District Courts of the United States and for Other Purposes, Washington, U.S. Government Printing Office.

DELISLE, Jean (1990): The Language Alchemists, Ottawa, University of Ottawa Press.

FISHMAN, Joshua (1972): Language and Nationalism - Two Integrative Essays, Rowley, Mass., Newbury House Publishers.

GARCÍA-MARTÍNEZ, Alfonso (1976): Idioma y politica, Hato Rey, Editorial Cordillera.

Gouvernement du Québec (1978): Charte de la langue française, Québec, Éditeur officiel.

Gouvernement du Québec (1991): Code des professions, Québec, Éditeur officiel.

GREENSPAN, E. L. (Ed.) (1993): Martin's Annual Criminal Code 1993, Aurora (Ont.), Canada Law Book Co.

KEDOURIE, Elie (1993): Nationalism, Fourth Expanded Edition, Oxford, Blackwell.

LAFRAMBOISE, Gilles (1992): "Language Industries", Language and Society, 41, Winter, pp. 7-9. 
LASA, Olga, PANIAGUA, Blanca y Liliana RAMOS (1993): "Un poco de historia", El Trujamán, VIII, 1, enero-marzo, pp. 3-5.

LASA DELGADO, Olga (1992): "La Ley del Idioma Oficial y los Traductores", El Trujamán, I, enero-agosto, 1, pp. 14-15.

LASA DELGADO, Olga: Private Communication, 28 February 1994.

LOPEZ LAGUERRE, María (1989): Bilingüismo en Puerto Rico, Río Piedras, Lopez Laguerre.

MUÑIZ-ARGUELLES, Luis (1989): "The Status of Languages in Puerto Rico", Forum, 1, pp. 28-32.

ORGAMBIDES, Fernando (1993): "El inglés es progreso", El País, Edición Internacional, 1 Feb., Cultura, Resumen mensual de Babelia, revista cultural, p. 14.

PINSKY, Gerald (Ed.) (1993): Puerto Rico, U.S.A. Business and Economic Facts, San Juan, Government of Puerto Rico, Economic Development Administration, Office ef Economic Research, December.

POUSADA, Alice (1992): "Review of Bilingüismo en Puerto Rico", Language Problems and Language Planning, 16 (1), Spring, pp. 80-83.

Puerto Rico, Leyes de Puerto Rico, Idiomas Oficiales, 51.

SIMON, Sherry (1989): L'inscription sociale de la traduction au Québec, Québec, Office de la langue française.

United States Bureau of the Census (1993): "Puerto Rico to Receive Economic, Social, and Housing 'Portrait' Drawn from 1990 Census Long Form", United States Department of Commerce News, CB93-18, 29 Jan.

VÉLEZ, Diana (1986): "Aspects of the Debate on Language in Puerto Rico", The Bilingual Review, XIII (3), September-December, pp. 3-12.

VÉLEZ, Jorge A. and C. William SCHWEERS (1993): "A U.S. Colony at a Linguistic Crossroads: The Decision to Make Spanish the Official Language of Puerto Rico", Language Problems and Language Planning, 17 (2), Summer, pp. 117-139. 